\title{
The Effects of Perfectionism Personality, Role stress and Job satisfaction on the Job Performance of Chinese Labors
}

\author{
Siwei Sun ${ }^{1, a}$ \\ ${ }^{1}$ School of Business, University of Nottingham, Ningbo 315100, China; \\ a2253900501@qq.com
}

Keywords: perfectionism, role stress, job satisfaction, performance, Chinese labor.

Abstract. The paper collected the data from questionnaires of 174 Chinese labors in 5 companies in Zhejiang Province, gained some results and gave some suggestion to managers.

\section{Introduction}

At present, there is few paper trying to figure out the relationships among perfectionism, role stress, job satisfaction and job performance of labor in Chinese context to help companies solve problem of labor management. At present, there is few paper trying to figure out the relationships among perfectionism, role stress, job satisfaction and job performance of labor in Chinese context to help companies solve problem of labor management. Perfectionism is considered to be a kind of personality and this personality will lead people to pursue high standards and no defect ${ }^{[1][2]}$. At the same time, Kemery asserted that there was some relationship between role stress and depression and anxiety $^{[3]}$. Lovas (2007) and Fleskova and Podolcova (2010) also once tried to explore relationship between satisfaction and organizational culture ${ }^{[4][5]}$. Company social responsibility and job satisfaction was also studied ${ }^{[6][7]}$, followed researches on relationship between satisfaction and leadership ${ }^{[8]}$. Campbell (1993) believed that performance was a good standard measuring outcomes of individuals and projects ${ }^{[9]}$.

\section{Hypothesis}

In this paper, author choose perfectionism, role stress, job satisfaction and performance as variables to figure out relationship among them. In this research, author put forward three assumptions(null hypothesis): $\mathrm{H} 1$ there is no relationship between perfectionism and job performance. $\mathrm{H} 2$ there is no relationship between role stress and job performance. $\mathrm{H} 2 \mathrm{a}$ there is no relationship between role conflict and job performance. $\mathrm{H} 2 \mathrm{~b}$ there is no relationship between role ambiguity and job performance.H3 there is no relationship between job satisfaction and job performance.

\section{Method}

All the questionnaires(in Chinese) were distributed among 174 labor as paper versions in three cities, including Ningbo, Taizhou and Cixi in Zhejiang Province in July 2015 in Cixi. The surveys including sixth five 7-scale questions(after neglecting the questions 38,43 in perfectionism measure; question 5 in job performance measure; which decreased the reliability,) after referring questionnaires from Rizzo (1970) ${ }^{[10]}$, .Hewitt, P.L., \& Flett, G.L. (1990) ${ }^{[11]}$, Edwards and Rothbard (1999) ${ }^{[12]}$, Williams, L. J., \& Anderson, S. E. (1991) ${ }^{[13]}$ and scales for demographic variables. Cronbach's Alpha of questionnaire was 0.790 .

\section{Results}

Descriptive analysis. From the perspective of role conflict, the mean score of males is 24.13 , which is higher than females (19.84). From the perspective of role ambiguity, the mean score of 
males is 13.93, which is higher than females (13.18). From the perspective of perfectionism, the mean score of males is 189.5, which is higher than females (189.01).From the perspective of job satisfaction, the mean score of males is 13.79 , which is lower than females (15.03). From the perspective of role conflict, the score of standard deviation of males is 9.74 , which is lower than females (11.48). From the perspective of role ambiguity, the score of standard deviation of males is 7.25, which is lower than females (7.73). From the perspective of perfectionism, the score of standard deviation of males is 26.671, which is higher than females (20.547).From the perspective of job satisfaction, the score of standard deviation of males is 3.93, which is lower than females (4.03).

Responses Discrepancy towards Variables between Different Demographic Variables. In order to figure out the responses difference towards variables between different demographic variables, author applied p-value to test samples difference. The test shows as below: different genders have significantly different attitudes on role conflict and satisfaction.(p-value are 0.009 and 0.046 respectively); people having different ages have significantly different attitudes on satisfaction ( $p$-value of satisfaction is all less than 0.05); people having different education levels have significantly different attitudes on role conflict, role ambiguity and satisfaction ( $\mathrm{p}$-value are $0.025,0.026$ and 0.048 respectively); people having different education levels have significantly different attitudes on role conflict, role ambiguity and satisfaction(p-value are $0.025,0.026$ and 0.048 respectively); people having different payment have significantly different attitudes on role ambiguity and job performance (p-value are 0.023 and 0.001 respectively).

Hypothesis test. In this part, author tested the hypothesis to explore the relationship among variables. Correlation analysis was applied to confirm the reliability of assumptions. Through applying correlation analysis, Null hypothesis 1 was confirmed to be rejected (" $r$ " was 0.200 , and followed with signal of "“**") and perfectionism was considered to have significant and positive effect on performance on 0.01 level. Null hypothesis 2 was confirmed to be rejected ("r" between role conflict and performance was -0.354 , and followed with signal of " "**"; " $r$ " between role ambiguity and performance was -0.367 , and followed with signal of “**") and role conflict and role ambiguity were considered to have significant and negative effect on performance on 0.01 level. Null hypothesis 3 was confirmed to be rejected (" $r$ " between job satisfaction and performance was 0.358 , and followed with signal of "**,") and satisfaction was considered to be positive obviously to performance on 0.01 level.

Regression analysis. 1. effect of role conflict on job performance

Table 1 Confidence interval

\begin{tabular}{lcclcccc}
\hline & B & Std.Error & $\begin{array}{c}\text { Standardized } \\
\text { Coefficients }\end{array}$ & $t$ & $P$ & $95 \%$ C.I. \\
\hline (Constant) & 37.111 & 0.842 & & 44.05 & $<0.001$ & $(35.449,38.774)$ \\
$\mathrm{A}(\mathrm{x} 1)$ & -0.145 & 0.035 & -0.302 & -4.158 & $<0.001$ & $(-0.214,-0.076)$ \\
\hline
\end{tabular}

The table 1 explained that the confidence coefficient is -0.145 , which meant that impact of role conflict on performance was negative and formula could be described as:

$\hat{y}=37.111-0.145 x 1$ (y represented performance and $\mathrm{x} 1$ represented role conflict)

Therefore, if role conflict reached a high degree, the performance would be decreased obviously.

2 . effect of role ambiguity on job performance 
Table 2 Confidence interval

\begin{tabular}{lrllcccc}
\hline & B & Std.Error & $\begin{array}{c}\text { Standardized } \\
\text { Coefficients }\end{array}$ & $t$ & $P$ & $95 \%$ C.I. \\
\hline (Constant) & 37.426 & 0.767 & & 48.805 & $<0.001$ & $(35.912,38.939)$ \\
B(x2) & -0.255 & 0.05 & -0.364 & -5.129 & $<0.001$ & $(-0.353,-0.157)$ \\
\hline
\end{tabular}

The table 2 explained that the confidence coefficient is -0.255 , which meant that impact of role ambiguity on performance was negative and formula could be described as:

$\hat{y}=37.426-0.255 \times 2$ (y represented performance, $\mathrm{x} 2$ represented role ambiguity)

Therefore, if role ambiguity reached a high degree, the performance would be decreased obviously.

3. effect of perfectionism on performance

Table 3

\begin{tabular}{lcccccc}
\hline & & Std.Erro & $\begin{array}{c}\text { Standardized } \\
\text { Coefficients }\end{array}$ & $T$ & $P$ & $95 \%$ C.I. \\
& & r & Coffict & & & \\
\hline (Constant) & 25.962 & 3.251 & & 7.987 & $<0.001$ & $(19.545,32.378)$ \\
$\mathrm{C}(\mathrm{x} 3)$ & 0.042 & 0.017 & 0.186 & 2.487 & 0.014 & $(0.009,0.076)$ \\
\hline
\end{tabular}

The table 3 explained that the confidence coefficient was 0.042 , which meant that impact of perfectionism on performance was positive and formula could be described as:

$$
\hat{y}=25.962+0.042 \times 3
$$

(y represented performance, $\mathrm{x} 3$ represented perfectionism)

Therefore, if the more labor pursued perfect on job, the better they did.

4. effect of satisfaction on performance

Table 4

\begin{tabular}{lccccccc}
\hline & B & $\begin{array}{c}\text { Std.Erro } \\
\mathrm{r}\end{array}$ & $\begin{array}{c}\text { Standardized } \\
\text { Coefficients }\end{array}$ & $T$ & $P$ & 95\%C.I. \\
\hline (Constant) & 27.727 & 1.419 & & 19.538 & $<0.001$ & $(24.926,30.528)$ \\
$\mathrm{D}(\mathrm{x} 4)$ & 0.431 & 0.094 & 0.33 & 4.578 & $<0.001$ & $(0.245,0.617)$ \\
\hline
\end{tabular}

The table 4 explained that the confidence coefficient was 0.431 , which meant that impact of satisfaction on performance was positive and formula could be described as:

$\hat{y}=27.727+0.431 x 4$

( $\mathrm{y}$ represented performance, $\mathrm{x} 4$ represented satisfaction)

Therefore, if the more labor felt satisfied with job, the better they did.

Recommendations. In this research, author got some results and would like to give some suggestions to managers. Firstly, managers should encourage and empower these labor with bonus or rewards to promote efficiency of work. Secondly, managers should pay attention to psychological or emotional reflections sparked by stress and give detailed help, so that the passion of labor would be promised. Thirdly, managers should enhance inter-communication and solve troubles for labor to improve satisfaction and rise job performance directly. 


\section{References}

[1]Flett, G. L., \& Hewitt, P. L. Perfectionism and maladjustment: An overview of theoretical, definitional, and treatment issues. Washington, DC: 2002. APA.5-31.

[2]Frost, R. O., Marten, P., Lahart, C., \& Rosenblate, R. The dimensions of perfectionism. Cognitive Therapy and Research. 1990. 14: 449-468.

[3]Kemery, E.R., Bedeian, A. G., Moosholder, K. W., \& Touliatos, J. Outcomes of role stress; a multisample constructive replication. Academy of Management Journal. 1985. 28 (2): 363-375.

[4]Lovas, L. Relationship of organizational culture and job satisfaction in the public sector.Studia Psychological. 2007.49(3):215-221.

[5]Fleskova, M. Spokojnost' zamestnancov verejnej spravy s pracovnymi podmienkami ako jeden zo socialnych aspektov spoloenskyzodpovedneho podnikania. Economic, Social, Enviromental and Legislative Aspects of the Corporate Social Responsibility I. Banska Bystrica: 2011.EF UMB.

[6]Vagnerova, M. Vyvojova psychologie II: Dospelost a stari. Praha: Karolinum. 2007.

[7]Fleskova, M. \& Podolcova, M. Podnikova kultúra a pracovna spokojnost' zamestnancov. 2010.Kosice: UPJS, 86-98.

[8]Havig, A. K., Skogstad, A., Veenstra, M. \& Romoren, T. I. The effects of leadership and ward factors on job satisfaction in nursing homes: a multileveled approach. Journal of Clinical Nursing. 2011.20:353-354.

[9]Campbell,J.P.,McCloy,R.A.,Oppler, S.H.and Sager, C.E. A theory of performance.San Francisco, 1993.CA:Jossey-Bass.35-69.

[10]Rizzo, J.R., House, R.J., \& Lirtzman, S.I. Role conflict and ambiguity in complex organizations. Administrative Science Quarterly. 1970.15:150-63.

[11]Hewitt, P. L., \& Flett, G. L. Perfectionism in the self and social contexts:Conceptualization, assessment, and association with psychopathology. Journal of Personality and Social Psychology. 1991. 60: 456-470.

[12]Edwards, B. D., \& Bell, S. T. Relationships between facets of job satisfaction and task and contextual performance. Applied Psychology: An International Review. 2008.57(3): 441-465.

[13]Williams, L. J., \& Anderson, S. E. Job satisfaction and organizational commitment as predictors of citizenship and in-role behaviors. Journal of Management. 1991.17:601-617. 